MARCIN Kopeć

Kraków

\title{
Rewitalizacja przemysłowych miast angielskich na przykładzie Barnsley
}

Polskie miasta stoją przed koniecznością transformacji znajdujących się w ich granicach obszarów zdegradowanych. W tym celu przygotowują plany działań, określane w Polsce jako programy rewitalizacji. Przygotowując te programy, władze miasta mogą opierać się nie tylko na obszernej coraz bardziej dostępnej w naszym kraju literaturze przedmiotu, nie tylko na doświadczeniach partnerów (firm konsultingowych, realizatorów projektów rewitalizacyjnych, praktyków zdobywających doświadczenia za granicą), ale także na tak zwanych najlepszych praktykach, przyglądając się doświadczeniom miast zachodnich.

Oczywiście, należy pamiętać, że doświadczeń tych nie można dosłownie przekładać na działania realizowane w Polsce - inne są bowiem systemy prawne, możliwości finansowe, poziom wyedukowania decydentów w zakresie problematyki odnowy miast, inna wreszcie skala problemu (kraje zachodnie regenerują swoje miasta od dziesięcioleci, w Polsce dotychczasowe działania miały bardzo ograniczony zakres).

Czy zatem warto korzystać z zagranicznych doświadczeń i wzorować na nich polskie programy rewitalizacji? Odpowiedzią może być teza postawiona przez K. Skalskiego, który pisze, że doświadczenia krajów osiągających lepsze niż Polska rezultaty w odnowie miast są cenne, nawet jeśli w niektórych z tych krajów tradycja kulturowa i zwyczaje administracji są Polsce bardziej, a w innych mniej bliskie. Chodzi o zwrócenie uwagi na rzeczy strukturalnie istotne, uniwersalne, zignorowanie zaś tych elementów rewitalizacji prowadzonej przez miasta zachodnie, które są drugorzędne, wynikające z kultury, tradycji administracyjnej i legislacyjnej danego kraju (Skalski 1996, s. 10).

Poniżej przedstawiony zostanie przykład działań rewitalizacyjnych, przeprowadzanych $\mathrm{w}$ angielskim mieście Barnsley.

\section{PodstaWowe INFORMACJE O BARNSLEY}

Barnsley to miasto położone w South Yorkshire, w środkowej Anglii, nad rzeką Dearne, ok. $20 \mathrm{~km}$ na północ od Sheffield. Populacja miasta to nieco ponad 72 tys. mieszkańców, w obszarze wpływów miasta (borough) żyje ok. 223,5 tys. ludzi.

Herb miasta zawiera łacińskie motto Spectemur Agendo (Oceń nas po naszych czynach) oraz wyobrażenie górnika i hutnika szkła, dla upamiętnienia dwóch gałęzi przemysłu, 
będących w przeszłości głównymi źródłami dochodów miasta i jego mieszkańców - górnictwa węgla kamiennego i hutnictwa szkła.

W 1249 r. miasto otrzymało przywilej królewski (Royal Charter), zezwalający na organizację cotygodniowego targowiska oraz corocznego targu. Począwszy od XVII w., stało się punktem przystankowym na trasie między większymi miastami: Leeds, Wakefield, Sheffield i Londynem - w wyniku generowanego ruchu w mieście rozwinął się handel i usługi, powstało wiele zajazdów. W tym okresie w Barnsley działały manufaktury tkackie, ma ono także długą tradycję w produkcji szkła, choć główna gałąź przemysłu, z której miasto było sławne, to górnictwo. W rzeczywistości większość kopalni znajdowała się w otaczających miasto wsiach - największą kopalnią, znajdującą się w samym mieście, była Barnsley Main, ale i tak była ona relatywnie niewielka (została zamknięta w 1991 r.). Na mocy ustawy o rządzie lokalnym (Local Government Act) z 1972 r., miasto przejęło kontrolę i włączyło w swoje granice okoliczne mniejsze miasteczka i wsie. Ostatnią kopalnię, działającą w regionie Barnsley, zamknięto w 1994 r. Z dawnych gałęzi przemysłu przetrwała do dziś jedynie produkcja szkła, reprezentowana przez dwa duże zakłady.

Wraz z restrukturyzacją przemysłu górniczego w latach 80 . ubiegłego wieku mieszkańcy miasta doświadczyli bezrobocia, a miasto - straty głównych źródeł swoich dochodów. Program zamykania kopalń skutkował ponadto kłopotami środowiskowymi i przestrzennymi, znaczny obszar miasta stanowiły bowiem tereny poprzemysłowe: hałdy górnicze, opuszczone budynki i szyby kopalniane oraz infrastruktura kolejowa, służąca wcześniej do transportu węgla. Miasto przez wiele lat prowadziło program rekultywacji terenów, czemu towarzyszyły inwestycje w nowy system drogowy oraz programy wspierające zatrudnienie byłych górników. Skalę działań może przybliżyć fakt, że od 1982 r. ponad 23 mln funtów wydano na rekultywację ponad 600 hektarów nieużytków poprzemysłowych, zamieniając je na nowe tereny inwestycyjne, rolnicze, parkowe i leśne.

Mimo tych działań, w 1999 r. region Barnsley uznawany był za jeden z najbiedniejszych regionów Europy. W przygotowywanym w roku 2000 dla 354 regionów Anglii zestawieniu, prezentującym wielowymiarowe ubóstwo, region Barnsley znalazł się na 16 pozycji, jako jeden z najuboższych regionów kraju. Wkrótce po ukazaniu się tego zestawienia miasto i region rozpoczęły korzystanie $\mathrm{z}$ funduszy unijnych.

Populacja miasta osiągnęła szczytową wielkość w 1971 r., z 226 tys. mieszkańców, i od tego czasu rozpoczął się trwający przez następne 30 lat powolny spadek liczby ludności. Liczba ludzi między 20 a 24 rokiem życia zamieszkujących Barnsley spadła w latach 1991-2003 o 40\%. W 2003 r. Barnsley pod względem społecznym było bardzo jednorodne, jego mieszkańcy to w 99\% biali Brytyjczycy, w 99\% urodzeni w Wielkiej Brytanii (jeden z najwyższych wskaźników w całej Anglii i Walii). 23\% obywateli to osoby będące specjalistami i menedżerami, co było wynikiem o 10\% mniejszym od średniej krajowej. Osoby z wykształceniem co najmniej średnim to ok. $11 \%$ populacji, co było wynikiem lepszym niż w 1991 r. (8\%), ale jednocześnie sytuowało miasto znacznie poniżej średniej krajowej, wynoszącej $20 \%$.

Oferta edukacyjna Barnsley przez wiele lat odbiegała niekorzystnie, pod względem standardów, od średniej krajowej. Sytuacja uległa zmianie i Barnsley College, usytuowany w kilku gmachach rozrzuconych w centrum miasta, jest obecnie jedną z największych szkół wyższych w Europie. Ponadto Uniwersytet w Huddersfield otworzył niedawno w mieście swój kampus, zwany University Centre Barnsley. 
W 2003 r. centrum miasta nie oferowało praktycznie możliwości zakupu mieszkania, podobnie sytuacja miała się także w przypadku powierzchni biurowej (jej wielkość w 2003 r. w całym mieście wynosiła około 70 tys. m²). W ciagu 30 lat poprzedzających działania rewitalizacyjne praktycznie nie prowadzono nowych inwestycji budowlanych w ścisłym centrum miasta. Działający w centrum targ otwarty we wtorki, środy, piątki i soboty, jest największą w mieście powierzchnią targową, jednakże ostatnie 10 lat to okres powolnego zamierania jego aktywności. Wciąż jest on popularny wśród lokalnej ludności, zwłaszcza ludzi starszych. Niewątpliwie to targ stanowi ważny element ożywienia centrum, dlatego wszelkie zmiany służące rozwojowi obszaru śródmiejskiego muszą uwzględniać ten właśnie punkt przestrzeni i gospodarki miejskiej. Dostępna przestrzeń komercyjna charakteryzowała się dużym zróżnicowaniem pod względem oferowanego standardu i przestarzałą infrastrukturą w porównaniu do innych miast regionu. Podaż na rynku przestrzeni komercyjnej obejmowała budynki z czasów wiktoriańskich, poddane działaniom konserwatorskim, z przestrzenią sklepową głównie na parterze, a także inne odnowione lokale (przede wszystkim z przeznaczeniem na biura), zazwyczaj o dość dobrym standardzie.

Rynek czasu wolnego ograniczony był w praktyce do oferty pubów i klubów, ewentualnie do restauracji i kina. W centrum znajdują się dwa hotele, dość duże i dobrej jakości, jednakże liczba miejsc hotelowych w mieście jest niewystarczająca. Miasto i okolice oferują tereny parkowe i zielone, zachęcające do dłuższych spacerów oraz rekreacji, m.in. wędkowania. Miasto posiada trzy muzea i planuje otwarcie czwartego, zlokalizowanego w urzędzie miasta, który to projekt nazwany został Doświadcz Barnsley (Experience Barnsley). Obecnie gospodarka miasta transformuje w stronę sektora usług.

\section{GŁÓWNI AKTORZY PRZEMIAN MIASTA}

W 2002 r. rada miejska wraz z lokalnymi partnerami zapoczątkowała wielką akcję konsultacji nazwaną Barnsley Przemyślane na Nowo (Rethinking Barnsley), co było wstępem do opracowania planu działań (programu rewitalizacji), koncentrującego się na centrum miasta, nazwanego Przebudową Barnsley (Remaking Barnsley).

Za rozwój gospodarki miasta odpowiedzialna jest specjalnie powołana do tego Agencja Rozwoju Barnsley (Barnsley Development Agency). Jest to organizacja partnerska najważniejszych graczy odpowiedzialnych za rozwój gospodarczy i rewitalizację miasta - rady miasta Barnsley i Izby Przemysłowo-Handlowej w Barnsley. Łączy ona umiejętności, doświadczenia i kontakty partnerów w jednym specjalnie przygotowanym punkcie kontaktu, którego celem jest asystowanie nowym przedsięwzięciom gospodarczym i zachęcanie do inwestowania w mieście. Jej zadaniem jest wspieranie biznesu i społeczności lokalnej.

Wspieranie biznesu. Agencja dostarcza informacji o ofercie inwestycyjnej (dostępnych pod inwestycje działkach), powierzchni pod wynajem, asystuje w zdobyciu funduszy na inwestycje (w tym grantów), doradza w planach rozwojowych firm planujących relokację na teren Barnsley, a także pomaga w przeszkoleniu pracowników oraz wspiera aktywność lokalnej społeczności, szczególnie w zakresie kreowania nowych miejsc pracy bądź zdobywania nowych umiejętności zawodowych. Wspiera też firmy działające na terenie miasta. Do tej pory przyczyniła się do powstania ponad 5,5 tys. miejsc pracy i zainwestowania w mieście przez firmy z sektorów produkcji żywności, telekomunikacji i rozrywki ponad 
250 mln funtów. W porównaniu do 1999 r. miasto zanotowało (dane z 2004 r.) 8\% wzrost liczby działających firm i podobny procentowy wzrost miejsc pracy, przy czym nastąpiła wyraźna zmiana struktury zatrudnienia z produkcyjnej (spadek o 10\%) na usługową (wzrost o 13\%).

Wspieranie społeczności lokalnej. W ramach Agencji działa przedsiębiorstwo socjalne (Social Enterprise Barnsley), koordynujące program społeczny Przejściowy Rynek Pracy (Barnsley Transitional Labour Market Programme) oraz Barnsley Options Team, zespół indywidualnych doradców, pomagających mieszkańcom w uzyskaniu zatrudnienia, szkoleń i praktyk. Agencja wspiera przedsiębiorstwa socjalne, pomagając społeczności lokalnej w ich zakładaniu, a następnie w działalności. Doradcy Agencji pomagają w planowaniu działalności biznesowej, zdobywaniu funduszy (w tym grantów), marketingu i promocji, zatrudnieniu personelu, pośredniczą także w kontaktach z innymi wspierającymi instytucjami. Pomoc udzielana jest bezpłatnie. Obecnie Agencja służy radą 51 przedsiębiorstwom socjalnym, oferującym usługi z zakresu opieki nad dziećmi, recyklingu, budownictwa, działalności sportowej i obsługi komputera. Program Przejściowy Rynek Pracy, adresowany jest do bezrobotnych, polega na wsparciu osób pozostających trwale bezrobotnymi, a także osób zagrożonych wykluczeniem społecznym i potrzebujących pomocy (niepełnosprawnych, samotnych rodziców). Pomaga w zdobyciu pracy, a także oświadczenia i kwalifikacji.

Realizacja Planu działań posiada wsparcie najważniejszych podmiotów działających w mieście w celu jego rozwoju gospodarczego: Regionalnej Agencji Rozwoju (Regional Development Agency), rady miasta, Izby Przemysłowo-Handlowej (Barnsley Chamber of Commerce and Industry), inwestorów ulokowanych w mieście, a także mieszkańców.

\section{WIZJA ROZWOJU MIASTA}

Barnsley realizuje program rozwoju, którego celem jest przekształcenie go w Miasto Targowe XXI wieku. Ambitne plany i budżet wielkości $380 \mathrm{mln}$ funtów to podstawy dla tej transformacji. Proces przekształceń rozpoczął się w listopadzie 2000 r., wraz z przeprowadzonymi podczas weekendu konsultacjami Barnsley Przemyślane na Nowo (Rethinking Barnsley), które pozwoliły na zapoznanie się z pomysłami na rozwój miasta wszystkich mieszkańców - od dzieci do emerytów, z udziałem zawodowych architektów, planistów miejskich, konsultantów specjalizujących się w sferze przekształceń urbanistycznych, deweloperów i władz miejskich. W wyniku tych konsultacji powstała Wizja Miasta - stawiająca zadanie wykreowania idealnego Miasta Targowego XXI wieku - nowoczesnej wspólnoty zapewniającej miejsca pracy, dostęp do kultury i sztuki, dobre warunki zamieszkania, odpoczynku i zakupów oraz bogactwo szans dla mieszkańców i działających na jego obszarze firm.

Konstruując Wizję Rozwoju Miasta, jego mieszkańcy zauważyli, że miasto musi wyróżniać się spośród innych, stać się dynamicznym miejscem zamieszkania, zatrudnienia oraz rozwoju kulturalnego dla swoich mieszkańców, zdobyć znaczenie w skali całego kraju, gdzie powinno być znane tak samo ze swoich gospodarczych i kulturalnych sukcesów, jak i rozwoju urbanistycznego i wykorzystania otaczających go terenów rolniczych. Twórcy wizji chcieliby wpłynąć na decydentów, aby włączyli się oni aktywnie w przeprowadzenie odnowy miasta, której celem jest zbudowanie pięknego miasta, z którego dumni mogliby być jego mieszkańcy. 
Wizja przedstawia miasto w 2033 r. jako Miasto Targowe XXI wieku, z centrum otoczonym przez ,żyjący mur” (okalający obszar ok. $0,7 \mathrm{~km}^{2}$ centrum, będący nowoczesną interpretacją średniowiecznych murów miejskich, definiujący fizyczne granice centrum miasta, wyznaczający obszar wzmożonej aktywności i natężenia doświadczeń, będący linią ożywienia, ale nie podziału, sugerujący znajdujące się w jego wnętrzu możliwości; ważnym elementem tej realizacji będą punkty wejścia - bramy, które muszą być najwyższej jakości obiektami; mur nie może być odbierany jako bariera, tworzące go struktury muszą odznaczać się zróżnicowaniem (różne style konstrukcji pomimo jednakowej wysokości zabudowy) i porównywalnymi, wysokimi standardami; założeniem jest, że szczyt muru (widok przez okna najwyższych pięter i z tarasów na dachach) będzie dostępny dla wszystkich, z dobrze rozwiniętą sferą kulturalną i rozrywkową (kina, teatry, galerie, festiwale filmowe, restauracje). Miasto zapewni dobrej jakości miejsca do życia i pracy, promować będzie zrównoważony rozwój (zwłaszcza poprzez zastosowanie odnawialnych źródeł energii, nowoczesne rolnictwo). Charakteryzować je będzie architektura wysokiej jakości, piękne projekty wpasowane w dobrze rozwinięte, historyczne centrum z tradycjami targowymi.

Dla realizacji tego projekt wyznaczone zostały bardziej szczegółowe cele, takie jak:

- stworzenie silnego obszaru centralnego, który będzie pracował wspólnie z otaczającymi go mniejszymi miejscowościami dla dobra regionu,

- jasne rozróżnienie między obszarami miejskimi a obszarami rolniczymi,

- wykreowanie dynamicznego, zróżnicowanego centrum, dostępnego i spełniającego oczekiwania wszystkich mieszkańców (miejsca zamieszkania, pracy, zabawy, zakupów, nauki, zachęcającego do odwiedzin),

- wykreowanie centrum jako miejsca wyróżniającego się,

- stworzenie pięknego Barnsley (wykorzystanie dziedzictwa architektonicznego, zainwestowanie w jakość formy architektonicznej, myślenie przyszłościowe).

Dla stworzenia śmiałego nowego planu centrum, wyróżniającego go od reszty miasta, zaproponowano:

- wykreowanie rodzaju ,żyjącego muru” otaczającego centrum (łańcuch budynków i przestrzeni - parków, oświetlenia miejskiego),

- stworzenie „nowych bram” (punktów wejścia) do centrum,

- wybudowanie ,nowego dworca” jako bramy do centrum dla korzystających z transportu publicznego,

- wzmocnienie i wyróżnienie głównych ciągów komunikacyjnych, prowadzących do najważniejszych miejsc w mieście, w szczególności zaś do dworca i centrum,

- wzmocnienie innych głównych ulic i przestrzeni miejskich (jasne zidentyfikowanie hierarchii tych miejsc, poprawa standardów budynków i przestrzeni miejskich tak, aby odzwierciedlały wagę tych miejsc, ze szczególnym uwzględnieniem urzędu miasta),

- wybudowanie nowej przestrzeni targowej (zarówno otwartej, jak i zabudowanej; targ powinien zostać przekształcony w przestrzeń o zróżnicowanym przeznaczeniu, otwartą dłużej w ciagu dnia i przez większą liczbę dni w tygodniu; wymaga to wybudowania nowej siedziby targu, dopasowanej do nowych funkcji centrum miasta; powinien powstać także element przykuwający uwagę, taki jak fontanna lub rzeźba, wokół którego jednakże toczyłoby się normalne życie, np. rozkładane byłyby 
stoiska w dni handlowe; otoczenie targu powinno zostać otwarte na różnego rodzaju aktywność gospodarczą, jak kawiarnie, puby, małe sklepiki),

- wykreowanie zdefiniowanych kwartałów zabudowy (odróżnianych pod względem ich charakteru, użytkowania lub prowadzonej działalności),

- stworzenie systemu mniejszych ulic, kwartałów i działek (spojrzenie na miasto jako na zbiór tysiąca pomysłów, nie zaś centralnie zdefiniowany i zunifikowany twór miejski),

- wykreowanie niewielkiego i zróżnicowanego centrum (żywego, zamieszkanego przez mieszkańców, pełniącego zróżnicowane funkcje, łączącego funkcje mieszkaniowe i komercyjne na jednym obszarze),

- stawianie na gęstość zabudowy, przy jednoczesnym zróżnicowaniu wysokości budynków (wykorzystanie naturalnej topografii miasta dla wyższych budynków),

- zachęcanie do zróżnicowania typów budynków (preferowanie budynków „łatwych w użyciu, łatwych do zmiany i łatwych do zrozumienia”, pełniących zróżnicowane funkcje i zachowujących najwyższe standardy),

- dopasowanie budynków i ulic (partery budynków muszą odpowiadać naturze ulicy i przestrzeni przed frontem budynku - celem ożywienia ulic),

- zapewnienie bezpiecznej i atrakcyjnej sfery publicznej (wykreowanie wysokiej jakości ulic i przestrzeni publicznych, zróżnicowanych na miejsca żywe i aktywne oraz miejsca ciche i spokojne).

Ważnym elementem rozwoju jest poprawa dostępności komunikacyjnej miasta. Oprócz rozwoju transportu publicznego, plan zakłada rozbudowę parkingów, w tym działających w systemie Park\&Ride - ulokowanych na peryferiach miasta, do którego centrum można dostać się transportem publicznym, a opłata za parking stanowi jednocześnie opłatę za transport publiczny. Rozwój tego systemu pozwoli na wyeliminowanie ruchu samochodów osobowych w ścisłym centrum miasta, ograniczając ruch w ramach ,żyjącego muru” do transportu publicznego i w niewielkim, niezbędnym zakresie (dostawy towarów, służby techniczne i ratunkowe) transportu prywatnego.

„Żyjący mur” otoczony będzie pierścieniem zieleni. Realizacja muru przewidziana jest na trzydzieści lat od uchwalenia planu działań, ale pierścień zieleni to realizacja krótkoterminowa, dwuletnia. Kształtowanie krajobrazu i sadzenie roślinności obok muru w sposób symboliczny ma zestawić egzystujące obok siebie i tworzące jedną całość przestrzeń miejską i przestrzeń okołomiejską, będąc jasnym odgraniczeniem między miastem a jego otoczeniem.

Plan zakłada wyznaczenie siedmiu obszarów na terenie miasta: pierwszy z nich przeznaczony ma być głównie na budownictwo mieszkaniowe, drugi to obszar zajmowany przez kampus, college wraz z kinem i parkiem, trzeci to dzielnica sklepików, restauracji, kawiarenek, czwarty to otoczenie centrum komunikacyjnego wraz z nowym dworcem autobusowym, piąty to obszar targowiska i jego komercyjnego otoczenia, szósty to obszar przeznaczony pod rozrywkę, zaś siódmy to komercyjne i administracyjne centrum. W uzupełnieniu wyznaczony został dodatkowy obszar obejmujący miejskie przestrzenie publiczne, zlokalizowany na styku pozostałych i spinający miasto w jedną całość, oraz obszar obejmujący najważniejsze nowe inwestycje planowane do realizacji w ścisłym centrum miasta.

Podobny zestaw postulatów stworzony został w stosunku do otoczenia miasta. Celem jest zapewnienie zróżnicowania społeczności lokalnych, z jednoczesnym wzrostem do- 
stępności do rynku pracy poprzez zwiększenie mobilności ich członków i lepszy dostęp do nowości technicznych. Ważnym elementem jest park w dolinie rzeki Dearne, będący głównym zielonym ciagiem pełniącym rolę osi łączącej społeczności zamieszkujące otaczające Barnsley mniejsze miejscowości. Przyjęte cele szczegółowe to m.in.: równowaga między środowiskiem naturalnym i przekształconym przez człowieka (ochrona środowiska i krajobrazu, naprawa szkód powstałych z winy człowieka, z jednoczesnym zapewnieniem rozwoju i żywotności miejscowości otaczających Barnsley), zwartość przestrzenna miasteczek, zapewnienie realizacji podstawowych potrzeb w bezpośrednim otoczeniu miejsca zamieszkania, koncentracja aktywności społecznej, instytucjonalnej i gospodarczej w ramach poszczególnych miejscowości, zróżnicowanie zabudowy, zoptymalizowanie gęstości zabudowy i przeznaczenia działek, udoskonalenie korytarzy transportu publicznego, uwzględnienie wartości historycznych i tradycji, postawienie na bezpieczeństwo obywateli.

\section{Przebudowa Barnsley - Strategiczny Schemat Rozwoju NA LATA 2003-2033}

Za wizją przyszła konieczność uwzględnienia niezbędnych zmian w postaci jasnego planu na przyszłość. Plan działań zawiera zarys projektów i zmian, które doprowadzą w ciągu najbliższych 30 lat do kompleksowych zmian centrum miasta.

Przebudowa Barnsley (Remaking Barnsley) oznacza dla mieszkańców szansę na nowe miejsca pracy oraz na stworzenie lepszego miejsca do pracy, życia i odpoczynku. Dla przedsiębiorców i deweloperów projekt rewitalizacji centrum oznacza szanse rozwoju i szanse na nowe inwestycje.

We wstępie autorzy napisali, że miasto rozpoczęło 30-letni proces realizacji swoich marzeń - pierwszy i być może najbardziej istotny krok został zrobiony: miasto i jego władze wypracowały wizję przyszłości, długoterminowy plan, który można łatwo przystosować do nowych wyzwań, przyszłych zmian gospodarczych i społecznych, oparty na koncepcji wykreowania wysokiej jakości środowiska miejskiego, stworzony przez i dla mieszkańców Barnsley.

W procesie tworzenia Planu Działań wzięte zostały pod uwagę postulaty całej społeczności miasta, włączając w to uczniów, właścicieli nieruchomości w całym regionie, przedsiębiorców, ludzi dojeżdżających do pracy czy na zakupy do miasta, wreszcie radnych miejskich.

Na potrzeby marketingu miasta powstało hasło reklamujące Barnsley jako „,miejscowość przypominającą położone na wzgórzach miasteczka Toskanii, z czerwonymi dachami domów lśniącymi jak czerwone dorodne pomidory prosto z rynku w Barnsley, w świetle neonów nowego dworca autobusowego". Koncepcja rozwoju miasta oparta została na obserwacji miasta podobnej wielkości, ale o nieporównywalnie większej urodzie: Lucca w Toskanii. To właśnie miasteczko, z jego średniowiecznym murem, otaczającym położone na wzgórzu średniowieczne centrum, stało się dla autorów projektu przekształceń Barnsley idealnym modelem, do którego zmierzać powinno Barnsley w procesie odnowy i rozwoju. Oczywiście, model ten musiał zostać dostosowany do współczesnych potrzeb i standardów. 
Symbolem zmian zachodzących w Barnsley jest świetlna aureola otaczająca miasto, umieszczona w znaku graficznym firmującym program zmian, a także wytworzona przy pomocy efektów świetlnych nad miastem w skali, która pozwala na jej dostrzeżenie ze znacznej odległości. Zamontowanie tej instalacji było pierwszym elementem realizacji Planu Działań.

W ramach Planu Działań przewidziana jest realizacja ośmiu projektów na obszarze ścisłego centrum miasta. Część z nich sfinalizowano w ostatnich dwóch latach, inne przewidziane są do realizacji do $2011 \mathrm{r}$. Te projekty to:

1. Nowy urząd miasta (Westgate Civic Offices) - prace rozpoczęły się w październiku 2005 r. i w ich wyniku powstał nowoczesny pięciopiętrowy biurowiec wysokiej klasy, pozwalający na zgromadzenie rozproszonych dotychczas w kilku miejscach wydziałów. Wartość projektu to ok. 9,5 mln funtów. Oddany pod koniec 2006 r. budynek stanowi część planowanego nowego centrum administracyjnego i komercyjnego. Jego realizacja umożliwia wyburzenie (przewidziane na 2008 r.) starego głównego budynku urzędu, co pozwoli na wybudowanie na jego miejscu nowego centrum handlowego (Barnsley Markets).

2. Gateway Plaza - planowany do ukończenia na wiosnę 2008 r. nowoczesny kompleks, składający się z biurowca z przewidzianą przestrzenią handlową, kawiarnią, parkingiem podziemnym i luksusowymi apartamentami. W drugiej fazie planowane są także hotel i centrum rozrywki. Prace nad realizacją projektu rozpoczęły się od budowy części mieszkalnej (apartamenty) w 2005 r. Przewidywana wartość projektu to ok. 34 mln funtów.

3. Barnsley Markets (nowe centrum targowe) - obecnie funkcjonujące targowisko to wielopiętrowy budynek wybudowany we wczesnych latach 70. ubiegłego wieku, mieszczący także - na wyższych piętrach - urząd miasta (przeniesiony już do nowego obiektu). Duży i brzydki kompleks dominuje nad biznesowym centrum miasta. Gmina wspólnie z partnerami (m.in. firmą deweloperską) planuje przebudowanie targowiska, w wyniku czego powstanie nowe centrum komercyjne o powierzchni ponad 90 tys. $\mathrm{m}^{2}$. Przeznaczenie nowego obiektu to tradycyjne targowisko (w standardach XXI w.), z towarzyszącymi mu restauracjami i kawiarniami, nowym sklepem wielkopowierzchniowym, wieloekranowym kinem, kilkoma poziomami sklepików oraz apartamentami. Powstanie tym samym doskonałe miejsce do zakupów i rozrywki, połączone z resztą centrum, dające nowe miejsca pracy i będące atrakcją dla osób odwiedzających miasto. Rozpoczęcie prac zaplanowano na początek 2008 r., zakończenie na 2011 r., a przewidywana wartość projektu to 180 mln funtów.

4. Civic Hall i Ogrody Mandeli (Mandela Gardens) - Civic Hall to cenny historyczny budynek z czasów wiktoriańskich, wpisany na listę zabytków, w którym do 1998 r. działał teatr. Projekt przewiduje połączenie zrekonstruowanego budynku z nową, trzypiętrową częścią, gdzie pod jednym dachem ulokowane zostaną sklepy z rękodziełem i wyrobami artystycznymi, przestrzeń wystawowa oraz przestrzeń z przeznaczeniem na różnego rodzaju wydarzenia artystyczne. Przewidziane jest także miejsce na gminne centrum informacji dla mieszkańców. Mandela Gardens to największa przestrzeń zielona w ścisłym centrum miasta, stanowiąca otoczenie dla Civic Hall, wymagająca prac porządkowych i upiększających. Miasto zabezpieczyło środki na ten projekt i prace zostały rozpoczęte. Projekt podzielono na dwie fazy - pierwsza przewidywana do zakończenia w 2007 r., druga w 2008 r. Jego wartość to 15 mln funtów.

5. Queens Hotel - planowana do zakończenia w 2007 r. przebudowa byłego hotelu na prestiżową przestrzeń biurową, zlokalizowaną w samym sercu miasta między nowym dwor- 
cem a centrum Civic Hall, niedaleko od nowego centrum handlowego. Projekt jest w całości realizowany przez lokalną firmę z jej środków.

6. Barnsley Transport Interchange (nowy dworzec) - warty $24 \mathrm{mln}$ funtów projekt, łączący w jednym miejscu miejski transport autobusowy, transport kolejowy, regionalny transport autobusowy oraz postój taksówek, w otoczeniu sklepów, parkingu dla samochodów oraz centrum informacji dla podróżnych. Budynek nowego dworca autobusowego, oddany do użytku w maju 2007, pozwala na bardziej komfortowe oczekiwanie na autobus, zapewniając bieżącą informację dotyczącą rozkładów jazdy (na licznych ekranach, osobnych dla każdego stanowiska autobusowego), umożliwia dokonanie zakupów w zapleczu handlowym, uzyskanie informacji o systemie transportowym miasta i regionu w centrum informacyjnym oraz bezpośrednie połączenie ze stacją kolejową.

Analizy wykazały, że rozwój miasta spowoduje wzrost liczby mieszkańców, liczby odwiedzających miasto w celu zakupów i dojeżdżających do pracy, co spowoduje wzrost zapotrzebowania na środki transportu i na nową infrastrukturę transportową, włączając $\mathrm{w}$ to nowe rozwiązania komunikacyjne z nowym dworcem autobusowym. Te zmiany będą stanowiły niezbędne wsparcie dla innych zmian zachodzących w mieście - dobrze rozwinięty transport publiczny był i jest warunkiem koniecznym dla realizacji wizji rozwoju miasta. Zmiany w systemie transportu to nie tylko inwestycja w nowy dworzec, ale także związane z nią zwiększenie liczby połączeń i kierunków docelowych. Barnsley to obecnie jedyne miasto regionu posiadające bezpośrednie połączenie z portem lotniczym w Doncaster. Możliwości połączeń uzupełnia oferta połączeń kolejowych do większych miast środkowej Anglii.

Osobnym, choć powiązanym projektem, było przebudowanie Midland Street, ulicy biegnącej wzdłuż byłej linii kolejowej, stanowiącej wcześniej wysoce nieatrakcyjną bramę do centrum miasta. Wschodnia strona ulicy podlega obecnie przebudowie w ramach realizacji projektu przebudowy dworca. W wyniku połączenia z Kendray Street uformowany zostanie rodzaj rynku, Market Square, nowa przestrzeń publiczna, wiodąca do nowego centrum handlowego.

7. Digital Media Centre (Centrum Mediów Cyfrowych) - inkubator przedsiębiorczości, posiadający łącznie 113 przestrzeni dla małych firm, sal z przeznaczeniem na spotkania biznesowe, sal konferencyjnych, tworzący warunki dla rozwoju małych innowacyjnych przedsiębiorstw. Wybudowany na miejscu parkingu (przykład kłopotów związanych z niską wartością nieruchomości w mieście i dużym ryzykiem inwestycyjnym - teren posiadał pozwolenie na budowę i przeznaczony był początkowo pod kino i centrum rozrywki, lecz nie udało się znaleźć inwestora dla realizacji tych zamierzeń) w sierpniu 2007 r., kosztem 9,7 mln funtów (60\% stanowiło dofinansowanie ze środków unijnych), stanowi miejskie centrum nowoczesnych technologii. Pierwsze nowe firmy rozpoczęły już działalność. Centrum zapewnia pełną obsługę (począwszy od infrastruktury, przez wspólną recepcję, możliwość korzystania z wyposażonej sali konferencyjnej oraz pokojów na spotkania biznesowe, skończywszy na sprzątaniu) za atrakcyjny czynsz. Możliwe jest także korzystanie z wyposażenia budynku przez małe firmy, nieulokowane fizycznie w centrum (jednoosobowe firmy prowadzone w domach) - przedsiębiorcy mogą za niewielką opłatą podpiąć się do sieci internetowej czy też skorzystać z adresu centrum jako adresu korespondencyjnego.

8. Town Hall Gardens (park miejski) - projekt przewidziany do realizacji w całości w 2007 r., kosztem 760 tys. funtów, zakłada stworzenie w pobliżu nowej siedziby urzędu miasta parku, który oprócz funkcji wypoczynkowej pełnić będzie także rolę miejsca wystawowego dla instalacji artystycznych. 
Inne projekty realizowane w mieście:

University College - szkoła wyższa (pierwsza tego typu instytucja pozwalająca na uzyskanie edukacji najwyższego stopnia) stymulująca wzrost edukacyjnych aspiracji młodych mieszkańców miasta. Z obecnością w mieście studentów władze miasta wiążą nadzieje rozwoju kulturalnego oraz wykreowania nowocześniejszej atmosfery.

Cooper Gallery - mała galeria prowadzona przez miasto, z kawiarnią i salą konferencyjna, umiejscowiona w historycznym budynku, odnowionym w 2000 r. kosztem 400 tys. funtów. Uważana za sukces władz miejskich i kulturalną atrakcję.

George Yard - jeden z kluczowych projektów zrealizowanych w ostatnich latach w centrum miasta. Historyczny budynek, wpisany na listę zabytków, odnowiony we współpracy z miastem.

Jak widać z powyższych przykładów, miasto przyjęło ambitny plan działań, rozkładając go jednakże w czasie i dopasowując do swoich możliwości finansowych. Wydaje się, że władze miasta nie muszą obawiać się konfrontacji z sentencją zapisaną w herbie miasta, pewne są dobrej oceny zaplanowanych i wykonanych działań (przy wsparciu innych organizacji, sektora prywatnego i samych mieszkańców). Nam pozostaje brać przykład z dobrze zaplanowanego i realizowanego procesu rozwoju miasta, zapoczątkowanego przez szerokie konsultacje społeczne, prowadzące do wytyczenia wizji rozwoju, przełożonej następnie przez specjalistów na konkretny plan działań. O poprawności procesu świadczą zrealizowane już projekty. Przykład działań podejmowanych przez władze Barnsley to jeden z możliwych modeli rewitalizacji miast poprzemysłowych, na którym wzorować się mogą polskie władze samorządowe, borykające się z problemami bezrobocia, porzuconych i zdegradowanych obszarów poprzemysłowych oraz zahamowaniem rozwoju gospodarczego miast.

\begin{abstract}
Podziękowanie
Autor dziękuje UK Trade \& Investment za umożliwienie $w$ dniach 7-12 października 2007 wyjazdu studyjnego, podczas którego doszło m.in. do spotkania z władzami miasta Barnsley i dzięki któremu mógł zapoznać się z działaniami z zakresu rewitalizacji obszarów poprzemysłowych w tym i innych miastach pótnocnej i środkowej Anglii.
\end{abstract}

\title{
Literatura
}

Skalski K., 1996, O budowie systemu rewitalizacji dawnych dzielnic miejskich, Krakowski Instytut Nieruchomości, Kraków

Wikipedia, http://en.wikipedia.org/wiki/Barnsley

www.barnsleydevelopmentagency.co.uk

Remaking Barnsley. Statement of Vision, Objectives and Principles, Draft for Consultation, 14 May 2002

Remaking Barnsley. Strategic Development Framework 2003-2033 


\section{Regeneration of the British industrial towns: case of the town Barnsley}

Polish cities need to redevelop post-industrial areas located within their boundaries. Cities' authorities, while preparing regeneration programs, can use best practices of Western European cities. One very good example is the case of the English town Barnsley.

Barnsley in earlier days was famous for coal mining, but the last pit was closed in 1994. With the demise of the coal industry, people suffered from unemployment and the town from losing its main revenue sources (in 2000, the town was ranked $16^{\text {th }}$ out of 354 most deprived district of England). Town was blighted by a very high incidence of post-industrial areas: disused colliery spoil tips, pit yards and the railway infrastructure which served the collieries.

For many years Barnsley has carried out an extensive land reclamation program, together with investments put into new road links and job creation schemes for the former colliery workers. Between 1982 and 2003, over 23 million GBP was spent on the restoration of over 600 hectares of derelict land.

Barnsley's vision is to be a $21^{\text {st }}$ Century Market Town. Those plans are prepared for the next 30 years, and the budget of 380 million GBP (including EU co-financing) constitutes the basis for the town transformation.

In 2002, the Barnsley Metropolitan Borough Council, together with local partners, started the Rethinking Barnsley weekend, a consultation project, which was the entry for preparing the urban centre regeneration program, called Remaking Barnsley. Planned and partly realised projects include construction of the new Barnsley Interchange - bus and coach station opened in May 2007, new cultural centre in the old Civic Hall, new commercial centre in Barnsley Markets, Digital Media Centre - opened in August 2007 - an incubator of new technologies, as well as new office and residential areas in the town centre. New business parks opened the new possibilities on the labour market.

A well planned and perfectly realised process of the town development, started by wide citizens' consultancy program, treated as a basis for establishing the town development vision, transformed then into an action plan and verified by already completed projects, is a good example to be copied by Polish towns. 